\title{
DOES MISOPROSTOL FOR INDUCTION OF LABOR INCREASE THE RISK OF UTERINE RUPTURE?
}

\author{
Kiswa Anggreany ${ }^{1}$, Mohammmad Luthfi Alkaff ${ }^{2}$ and Risanto Siswosudarmo ${ }^{3}$
}

\begin{abstract}
Background: Misoprostol is a synthetic prostaglandin E1 analogue which is now commonly used for induction of labor. Hyperstimulation is a complication of misoprostol that may lead to uterine rupture.

Objective: To find the association between misoprostol exposure for induction of labor with uterine rupture.

Methods: Case were all women who delivered in Sardjito and affiliate Hospitals from January 2007 to November 2012 with the diagnosis of uterine rupture. Controls were taken randomly from the same hospital. Chi square test and logistic regression model were used for statistical analysis.

Result and Discussion: There were 53 cases of uterine rupture and 199 controls. The incidence of uterine rupture was 53 over 64,244 deliveries or $0,08 \%$. Risk of of uterine rupture associated with misoprostol exposure was 1, 09 ( $\mathrm{Cl} 95 \%$ 0,52-2,2), while that of oxytocin exposure was 0,80 (Cl 95\% 0,35-1,85). Logistic regression analysis showed that the highest risk factor associated with uterine rupture was fetal weight $>$ 3500 (OR 3,46; $95 \% \mathrm{Cl} 1,48-8,56$ ) followed by parity (OR 2,56;95\% Cl 1,019-6,465) and vacuum extraction (OR 2,45;95\% Cl 0,94-6,39).

Conclusion: There was no association between misoprostol exposure with uterine rupture. Fetal weight $>3500$ gram, Parity more than 3 , and vacuum extraction increased the risk of uterine rupture associated with misoprostol use.
\end{abstract}

Keywords: Misoprostol, induction of labor, uterine rupture, fetal weight, parity.

\begin{abstract}
ABSTRAK
Latar belakang: Misoprostol adalah analog prostaglandin E1 sintetik yang sekarang banyak digunakan untuk induksi persalinan. Hiperstimulasi merupakan salah satu komplikasi induksi persalinan dengan misoprostol yang dapat mengakibatkan ruptur uterus .

Tujuan: Untuk mengetahui hubungan antara penggunaan misoprostol untuk induksi persalinan dengan kejadian ruptur uterus.

Metode : Kasus adalah semua ibu melahirkan di RS Sardjito dan RS afiliasi dari Januari 2007 sampai November 2012 yang mengalami ruptur uteri. Sebagai kontrol adalah ibu melahirkan di rumah sakit yang sama yang tidak mengalami ruptur uteri yang diambil secara random dengan perbandingan 1:4. Chi square test dan logistic regression model digunakan untuk analisis statistik.

Hasil dan Pembahasan : Terdapat 53 kasus ruptur uterus yang memenuhi kriteria kelayakan dan 199 kontrol. Insidensi ruptur uteri adalah 53 dari 64.244 persalinan atau $0,08 \%$. Risiko ruptur uteri yang berhubungan dengan pemakaian misosprostol adalah 1, 09 (Cl 95\% 0,52-2,2), sedang yang berhubungan dengan pemakaian oksitosin adalah 0,80 (Cl 95\% 0,35-1,85). Analisis regresi logistik menunjukkan bahwa faktor risiko terbesar yang berhubungan dengan kejadian ruptur uteri adalah berat janin > $3500(\mathrm{OR} 3,46 ; 95 \% \mathrm{Cl}$ 1,48-8,56) disusul dengan paritas (OR 2,56;95\% Cl 1,019-6,465) dan ekstraksi vakum (OR 2,45;95\% Cl 0,94-6,39).
\end{abstract}

Departemen Obstretri \& Ginekologi Fakultas Kedokteran UGM/RSUP Dr. Sardjito 
Kesimpulan: Tidak ada hubungan antara pemakaian misoprostol dengan kejadian ruptur uterus, tetapi berat janin > 3500 gram, paritas lebih dari 3, dan ekstraksi vakum menaikkan risiko ruptur uteri.

Kata kunci: Misoprostol, induksi persalinan, ruptur uteri, berat janin, paritas

\section{INTRODUCTION}

Misoprostol, a prostaglandin E1 analog, was first approved by the Food and Drug Administration (FDA) for the treatment of gastric ulcers, but it is now important in obstetric practice because of its uterotonic and cervical ripening actions. It has been now used widely to induce labor in term pregnancy and also to prevent postpartum hemorrhage. ${ }^{1}$ It is very effective for induction of labor either in premature rupture of membrane ${ }^{2}$, postdate pregnancy ${ }^{3}$ and pregnancy induced hypertension. ${ }^{4}$ It has also been used to induce labor in women with a history of previous cesarean section but the risk of rupture is still controversy. ${ }^{5}$

Although the use of misoprostol for induction of labor has been widely recognized, but there is no consensus about the optimum dose, frequency and route of administration for its safety. ${ }^{6}$ The recommended dose was $25 \mu \mathrm{g}$ given not less than 3-4 hourly. ${ }^{7}$

Hyperstimulation is one of the side effects of misoprostol can cause uterine rupture. There are several case reports of uterine rupture in women induced with misoprostol, especially with the history of secarea section. ${ }^{8}$

Several studies and reviews have been conducted to assess the effectiveness and safety of misoprostol but until now there has been no research with large scale that examines incidence of uterine rupture associated with misoprostol induction. The use of misoprostol induction in pregnant women is still off label, because the data security is still lacking. ${ }^{9}$

The purpose of the recent stdudy was to find out wether misoprostol was assiciated with the risk of uterine rupture in women using misoprostol for induction of labor.

\section{MATERIALS AND METHOD}

Case control designed was used for the study. Data were taken from medical records for 5 years from January 2007 to November 2012 in Sardjito Hospital and 5 affiliated Hospitals located at the Province of Jogjakarta and Central Java.

Cases were all pregnant women with gestational age more than 28 weeks with uterine rupture due not to trauma. These were obtained from medical records with a diagnosis code ICD 071.1 (International Classification of Diseases and related health problems) $10^{\text {th }}$ revision version for 2007). Hospitals that data have not been computerized they were gathered manually was recorded from the delivery room. Controls were those who gave birth without uterine rupture and were taken randomly from the same hospital with a ratio 1:4. Those who had rupture due to trauma were excluded.

Data were processed using SPSS version 16 using chi-square test and logistic regression models for statistical analysis.

\section{RESULTS AND DISCUSSION}

There were a total of 64,244 of deliveries during 5 years periode in the study hospitals. Fifty-three of them had uterine rupture and met the inclussion criteria (gestational age more than 28 completed weeks). Twelve from 53 cases of uterine ruptures were associated with misoprostol use. None of them had a history of cesarean section. A total of 199 deliveries were 
taken as control. A total of 252 samples then used for further analysis.

There were 54 women who were induced with misoprostol $(21,4 \%), 44$ were exposed to oxytocin (17,5\%), 23 to vacuum extraction $(9,1 \%)$ and $53(21 \%)$ women had uterine rupture (Table 1).

Table 1. Characteristics of Patients

\begin{tabular}{lcc}
\hline Variable & Frequency & Percent \\
\hline Age (years) & 44 & \\
$>35$ & 208 & 17.5 \\
$\leq 35$ & & 82.5 \\
Parity & 26 & \\
$>3$ & 226 & 10.3 \\
$\leq 3$ & & 89.7 \\
Fetal weight (g) & 25 & \\
$>3500$ & 227 & 9.9 \\
$\leq 3500$ & & 90.1 \\
Misoprostol-induced & 54 & \\
Yes & 198 & 21.4 \\
No & & 78.6 \\
Exposure to oxytocin & 44 & \\
Yes & 208 & 17.5 \\
No & & 82.5 \\
Vacuum extraction & 23 & \\
Yes & 229 & 9.1 \\
No & & 90.9 \\
Uterine Rupture & & \\
Yes & 53 & 21 \\
No & 199 & 79 \\
\hline
\end{tabular}

The association between misoprostol and uterine rupture was the main interest to investigate, as shown on table 2 . It seemed that the exposure of misoprostol did not increase the occurrence of uterine rupture. Uterine rupture is a catastrophic condition potetially leading to death both for mother and fetus if not promptly and adequately managed. The incidence of uterine rupture during 5 years period in this study was $0.08 \%$ (8 per 10,000 deliveries). It was similar with other reports that ranged from $0.07 \%$ to $0.17 \% .{ }^{10}$ The incidence was even lower for the unscarred uterus, $0.007 \%$ (0.7 per 10,000 deliveries) but it was much more higher for the scarred uterus. ${ }^{11}$ 
Table 2. Exposure of misoprostol to uterine rupture

\begin{tabular}{lcccc}
\hline \multicolumn{1}{c}{ Variable } & Rupture & No rupture & OR (CI 95\%) & P value \\
\hline $\begin{array}{l}\text { Misoprostol } \\
\text { Yes }\end{array}$ & 12 & 42 & & \\
$\begin{array}{l}\text { Misoprostol } \\
\text { No }\end{array}$ & 41 & 157 & $1,09(0,52-2,26)$ & 0,80 \\
\hline
\end{tabular}

The rate of uterine rupture was much higher in an attempt to do a vaginal delivery after cesarean section if misoprostol is used. One study showed that there were four out of 41 patient underwent uterine rupture. ${ }^{12}$ Other study found that the uterine rupture rate for patients attempting vaginal birth after cesarean section was significantly higher $5.6 \%$ in those who received misoprostol, than in those who did not, $0.2 \%{ }^{13}$

This present study showed that induction of labor using misoprostol did not increase the rate of uterine rupture because none of our patients induced by misoprostol had a history of previous cesarean section. In addition to history of scarred uterus, doses of misoprostol might also influence the occurrence of uterine rupture. The use of
$100 \mu \mathrm{g}$ gave rise to 2 out 29 patient undergoing uterine rupture $(6.89 \%)$ compared to none among 28 patients induced by Folley catheter. ${ }^{14}$ Another study found that there were two cases out of 64 women of who had uterine rupture induced with $100 \mu \mathrm{g}$ compared to none when induced with $50 \mu \mathrm{g} .{ }^{15}$ As our data on the dose of misoprostol were incomplete then the effect of dose on the occurrence of uterine rupture couldn't be analyzed.

Further analysis demonstrated that fetal wight increased significantly the rate of uterine rupture, followed by vacum extraction and parity more than three although they were not statistically significant (Table 3). Oxytocin exposure and maternal age did not have any effect on the occurrence of uterine rupture.

Table 3. Bivariate analysis showing variables potential to induce uterine rupture.

\begin{tabular}{|c|c|c|c|c|c|}
\hline No & Variables & Ruptur & No ruptur & OR (Cl 95\%) & p \\
\hline \multirow[t]{3}{*}{1} & Oxytocin exposure: & & & & \\
\hline & Yes & 8 & 36 & $0.80(0.35-1.85)$ & 0.61 \\
\hline & No & 45 & 163 & & \\
\hline \multirow[t]{3}{*}{2} & Vacuum Extraction: & & & & \\
\hline & Yes & 8 & 15 & $2.18(0.87-5.46)$ & 0,09 \\
\hline & No & 45 & 184 & & \\
\hline \multirow[t]{3}{*}{3} & Maternal age (years): & & & & \\
\hline & $>35$ & 11 & 33 & $1.31(0.61-2.82)$ & 0.47 \\
\hline & $\leq 35$ & 42 & 166 & & \\
\hline \multirow[t]{3}{*}{4} & Parity & & & & \\
\hline & $>3$ & 9 & 17 & $2.19(0.91-5.24$ & 0.07 \\
\hline & $\leq 3$ & 44 & 182 & & \\
\hline \multirow[t]{3}{*}{5} & Fetal weight & & & & \\
\hline & $>3500 \mathrm{gr}$ & 11 & 14 & $3,46(1,46-8,16)$ & 0,03 \\
\hline & $\leq 3500 \mathrm{gr}$ & 42 & 185 & & \\
\hline
\end{tabular}


To find out variables that gave the greatest influence on the occurrence of uterine rupture, a multivariate logistic regression model was caried out. It was shown that fetal weight more than $3500 \mathrm{~g}$, parity more than three and vaccum extraction were consistently related to uterine rupture. (Table 4).

Table 4. Multivariate analysis of variables potentially induce uterine rupture

\begin{tabular}{lccc}
\hline Variabel & OR & Cl (95\%) & p \\
\hline $\begin{array}{l}\text { Misoprostol induction } \\
\text { Yes }\end{array}$ & 1.15 & $0,53-2,49$ & 0,71 \\
No & 1 & & \\
$\begin{array}{l}\text { Parity } \\
>3\end{array}$ & 2,56 & $1,02-6,46$ & 0,04 \\
$\leq 3$ & 1 & & \\
Fetal Weight & & $1,48-8,56$ & 0,01 \\
$>3500$ gr & 3,56 & & \\
$\leq 3500$ gr & 1 & $0,33-1,92$ & 0,62 \\
$\begin{array}{l}\text { Oxytocin exposure } \\
\text { Yes }\end{array}$ & 0,80 & & \\
No & 1 & & 0,06 \\
Vaccum Extraction & & $0,94-6,39$ & \\
Yes & 2,45 & & \\
No & 1 & & \\
\hline
\end{tabular}

The cochrane systematic review conducted by Alfirevic found that oral misoprostol was effective for induction of labor, but the data were not big enough to draw a conclusion on the safety of its use. ${ }^{16}$ Review conducted by Homfrey and Munzozini concluded that it was not enough evidence to say that misoprostol under the tongue was safe for inducing labor. The authors suggested to do more studies with larger samples. ${ }^{17}$

The main risk factor found in this study was increased fetal weight more than 3,500 grams and it seemed to be clinically and statistically significant. The same result was demonstrated by Jastrow et al. who found that increased incidence of uterine rupture was influenced by increased fetuses fetal weight more than 3500 grams and much higher in fetus weighing more than 4000 grams. $^{18}$
The present study showed that maternal age didn't increased the risk of uterine rupture as the other investigator reported. ${ }^{19}$ Oxytocin was not asscociated with the increased risk for uterine rupture and even with hyperstimulation. This might be due to the limitted sample in the study with small dose. Higher dose had been reported to be asscoiated with maternal hyperstimulation but no rupture was encountered. ${ }^{20}$

The risk of getting rupture associated with the use vacuum extraction to deliver baby in this study was 2.45 (95\%, 0.94-6.39). which is not statistically significant but clinically important. Five cases who received misoprostol might have ruptured before vacuum extraction was done. Vacuum extraction was claimed to be a risk factor for uterine rupture. ${ }^{21}$ Parity more than three increased the rate of uterine rupture by 2.56 fold. This might be attributed to the thinner uterine wall as more child birth took place as proposed by Gardeil. ${ }^{22}$ 


\section{CONCLUSSION}

This study concluded that misoprostol was not asscociated with the incraesed rate of uterine rupture. On the other hand, fetal weight, parity and exposure to vacuum extraction during the second stage were dominant factors attributable to uterine rupture.

\section{REFERENCES}

1. Goldberg $A B$, Greenberg $M B$, and Darney $P D$. Misoprostol and Pregnancy. N Engl J Med 2001; 344 (1): 38-45.

2. Wing DA and Paul RH. Induction of labor with misoprostol for premature rupture of membrane beyond thirty six-weeks' gestation. Am J Obstet Gynecol 1998; 179:94-9.

3. Idris SB. Perbandingan keefektifan misoprostol dengan oksitosin untuk induksi persalinan pada kehamilan postterm. Thesis PPDS Obstetri dan Ginekologi 2001. Fakultas Kedokteran UGM Yogyakarta.

4. Kolderup L, McLean L, Grulon K, Safford K and Kilpatrick SJ. Misoprostol is more efficacius for labor induction than prostaglandin E2, but is it associated with more risk? Am J Obstet Gynecol 1999; 180: 1543-50.

5. Hee LC and Raynor BD. Misoprostol induction of labor among women with a history of cesarean delivery. Am J Obstet Gynecol 2001; 184:1115-7.

6. Mathews J, Mathai M, George A. Uterine rupture in a multiparaous women during labor induction with oral misoprostol. And Int J Gynecol Obstet 2000, 4344

7. ACOG Committee Opinion New U.S. Food and Drug Administration Labeling on Cytotec (Misoprostol) Use in Pregnancy. ACOG Committee on Obstetric Practice 2003, 283.

8. Guise JM, McDonagh MS, Osterweil P, Nygren $P$, Chan, BK, Helfand M. Systematic review of the incidence and consequences of uterine rupture in women with previous caesarean section. BMJ 2004;329:19

9. Hofmeyr G, Gülmezoglu AM, Pileggi C. Vaginal misoprostol for cervical ripening and induction of labor, Cochrane database [Art. No.: CD000941. DOI: 10.1002/14651858].2010
10. Gupta A, Nanda S. Uterine rupture in pregnancy: a five-year study. Arch Gynecol Obstet 2011; 283 (3):437-41.

11. Zwart JJ, Richters JM, Ory F, de Vries JI, Bloemenkamp $\mathrm{KW}$, van Roosmalen J. Uterine rupture in The Netherlands: a nationwide population-based cohort study. BJOG. 2009;116(8):1069.

12. Aslan $\mathrm{H}$, Unlu $\mathrm{E}$, Agar $\mathrm{M}$, Ceylan $\mathrm{Y}$. Uterine rupture associated with misoprostol labor induction in women with previous cesarean delivery. Eur J Obstet Gynecol Rep Biol; 2004; (113):45-48.

13. Plaut MM, Schwartz ML and Lubarsky SL. Uterine rupture associated with the use of misoprostol in the gravid patient with a previous cesarean section. Am J Obstet Gynecol 1999; 180:1535-42.

14. Afolabi B, Oyeneyin O, Ogedengbe O. Intravaginal misorotol vs. Folley catheter for cervical ripening and induction of labor. Int J Gynecol Obstet 2005; 89:263-67.

15. Majoko F, Magwali T, Zwizwai. Uterine rupture associated with use of misoprostol for induction of labor. Inter J Gynecol Obstet, 2002, 77-78

16. Alfirevic $Z$, Weeks A. Oral misoprostol for induction of labor. Cochrane database [Art. No.: CD001338. DOI: 10.1002/14651858]. 2010

17. Muzonzini G, Hofmeyr G. Buccal or sublingual misoprostol for cervical ripening and induction of labor. Cochrane database [Art. No.: CD004221. DOI: 10.1002/14651858]. 2010

18. Jastrow N, Roberge S, Gauthier RJ, Laroche L, Duperron L, Brassard N, Bujold E. Effect of birth weight on adverse obstetric outcomes in vaginal birth after cesarean delivery, 2010, 115:338-43

19. Zeteroglu S, Sahin GH, Sahin HA. Labor induction in pregnancies with advanced maternal age, 2006, 140-144

20. Wei SQ, Luo ZC, HP Qi, Xu H, Fraser WD. High dose versus low dose oxytocin for labor augmentation: a systematic review. Am J Obstet Gynecol 2010

21. Wang LY, Su TH, Lee R. Obstetrics uterine rupture: A 20 year clinical analysis. Taiwanese J Obstet Gynecol, 2004, 43:3

22. Gardeil F, Daly S, Turner JM. Uterine rupture in pregnancy reviewed restaurants. European $J$ of Obstetrics and gynecology and reproductive biology 1994, 56:107-110 